\title{
3
}

\section{When the Carnival is Over: The Case for Reform of Access to Royal Commission Records}

\author{
Hollie Kerwin and Maya Narayan
}

\section{Introduction}

Royal commissions occupy a complex position within the three arms of Australian Government. As executive bodies, they may be more amenable to characterisation as public record-keeping institutions than Chapter III courts, but the royal commission's central function of receiving evidence, often coerced, raises similar questions as to the appropriateness of permitting public access to their records.

At the same time, the royal commission is a fundamentally public event. Paralleled only by electoral voting and judicial determination, the royal commission draws an exceptionally direct line between the citizen and government. It casts lines out into public space: inviting —and at times compelling-individual witnesses to tell their stories, and recording testimony, before speaking back to tell 'public truths' and propose legal and social change. In this process, royal commissions are heralded as

1 The views expressed in this chapter are the authors' and do not in any way reflect those of their employers. The authors are grateful to Prue Gregory, Principal Lawyer, Knowmore, Dr Katie Wright, La Trobe University, and the National Archives of Australia for their assistance in the preparation of this chapter, and to Kerry Ford and Joel Townsend for their generous review of an earlier version of it. 
singularly able to 'get at the truth', ${ }^{2}$ and as a powerful instrument of governance that constructs and encourages public endorsement of certain, official knowledge, thereby also eliding or silencing other narratives. ${ }^{3}$ Despite their public significance, the royal commission remains an underresearched institution, especially in respect of its function as archive.

In this chapter, we seek to encourage attention to the 'royal commission as archive'. Engagement with the royal commission as archive, we suggest, raises risks, opportunities and imperatives for the continued remembrance of significant public issues, for critical engagement with the state archive and for unpacking the royal commission as an instrument of government. We argue that the records of these unique organs of government inquiry and public power remain in an unstable legislative and governmental compromise.

In response, this chapter proposes a sui generis regime for management of and access to the records of these unique organs of government inquiry and public power.

\section{The Royal Commission as Government Inquiry-A Complex Institutional Identity}

\section{Locating Royal Commissions in the Australian Constitutional Setting}

The royal commission has been described as the most ancient and dignified' organ of government inquiry. ${ }^{4}$ In many ways similar to a court, the royal commission has historically been defined by its power to compel individuals to give evidence and its capacity to make findings on broad matters of public and private importance, including misconduct, corruption, negligence and pressing legal and social issues. However, the royal commission is not a judicial entity. Formally an extension of the

2 Joyce Chia, 'Inquiring into Inquiries: The Review of the Royal Commissions Act' (2009) 94 Reform 49, 49.

3 Jeanine Purdy, 'Royal Commissions and Omissions' (1992) 17(1) Alternative Law Journal 32, 33; see also Hugh McDowall Clokie and J William Robinson, Royal Commissions of Inquiry: The Significance of Investigations in British Politics (1969, Octagon Books), 139-40 and 177; Gillian Cowlishaw, 'Inquiring into Aboriginal Deaths in Custody: The Limits of a Royal Commission' (2007) 7 Journal of Indigenous Policy 28, 31.

4 Clokie and Robinson, above n 3, 24-5. 
executive arm of government, the royal commission's position outside Parliament and the judiciary reflects 'the constitutional struggles which have centered around the royal prerogative' and attempts to restrict royal action to certain, defined modes of legal procedure. ${ }^{5}$

Despite the royal commission's foundation in British legal history, the institution remains relevant, important and a major facet of Australian government. At the Commonwealth level, for example, 133 commissions have been established under the Royal Commissions Act 1902 (Cth) since 1902. ${ }^{6}$ These commissions have considered various matters of national importance throughout the $20^{\text {th }}$ and $21^{\text {st }}$ centuries, including the sites of the seat of the Commonwealth Government (1903); 'industrial troubles' on Melbourne wharfs (1919-20); the basic wage (1919-20); monetary and banking systems (1935-37); Aboriginal land rights (1973-34); and drug trafficking (1981-83). ${ }^{7}$ More recently, the royal commission has been employed to investigate alleged corruption, complex crime and major institutional failures in the context of the 'HIH Insurance collapse' (2001-04), the Australian Wheat Board and the United Nations Oil for Food program (2005-06), the Home Insulation Program (2013-14), child sex abuse (2013-17) and the protection and detention of children in the Northern Territory $(2016-17) .^{8}$

Critically, despite the continued currency of the royal commission, there is no single or enduring institution known as 'the royal commission'.' Rather, while it is possible to speak of a royal commission as an institution of government, individual royal commissions are enlivened by the Crown to conduct particular inquiries. Unlike other forms of executive inquiry

\footnotetext{
5 Ibid 25.

6 See Parliament of Australia, Royal Commissions and Commissions of Inquiry (2015) <http://www. aph.gov.au/About_Parliament/Parliamentary_Departments/Parliamentary_Library/Browse_by_Topic/ law/royalcommissions\#1977>.

7 Ibid.

8 Ibid.

9 Accepting that there remain rare, permanent, subject-specific royal commissions in British legal history. See, for example, the Royal Commission into Historical Manuscripts appointed under royal warrant in 1869 and continuing (with amendments to the warrant) as part of the United Kingdom National Archives. See further, National Archives, Historical Manuscripts Commission Warrant (n.d.) <http://www.nationalarchives.gov.uk/information-management/legislation/hmc-warrant/>.
} 
carried out by government departments and law reform bodies, a royal commission ceases to exist when its particular inquiry concludes and the commission makes its report. ${ }^{10}$

Contemporary royal commissions continue to be created by the GovernorGeneral or the Governors of the Australian states by issue of letters patent, a mechanism by which the Monarch has historically made commands or determined rights. The letters patent compel certain peoplethe commissioners - to make inquiries in relation to certain matters (the terms of reference). Unsurprisingly, given the royal commission's continued evolution in the age of statutes, each inquiry is now supported by detailed legislation in each of the Australian states, territories and at the Commonwealth level. ${ }^{11}$

\section{Complicating the Picture}

Despite their technical position within the executive, the royal commission does not resemble or neatly reflect the methods of any single arm of government. ${ }^{12}$ As Clokie and Robinson have observed, royal commissions are a 'notable example of the wise combination of fact-finding and policy forming in the modern State'. ${ }^{13}$ In one sense, each commission is effectively independent of the executive, given that it is not directed by it except as to its composition, timelines and terms of reference (which are, of course, not wholly without some effect on their operation). ${ }^{14}$

10 Leonard Arthur Hallet, Royal Commissions and Boards of Inquiry (Law Book Company, 1982) 1. We discuss the implications of the impermanence of a commission in connection with its archive, below.

11 Legislation is required to empower royal commissions to compel the production of evidence; however, many modern royal commissions statutes go beyond mere provision of such a power: see, Royal Commission Act 1902 (Cth); Royal Commissions Act 1923 (NSW); Commissions of Inquiry Act 1950 (Qld); Royal Commissions Act 1968 (WA); Royal Commissions Act 1916 (SA); Commission of Inquiry Act 1995 (Tas); Royal Commissions Act 1991 (ACT); Inquiries Act 2014 (Vic) and Inquiries Act 1985 (NT).

12 Clokie and Robinson, above n 3, v, 2; see also Gregory J Inwood and Carolyn M Johns, 'Why Study Commissions of Inquiry' in Gregory J Inwood and Carolyn M Johns (eds), Commissions of Inquiry and Policy Change: A Comparative Analysis (Toronto Press, 2015) 3.

13 Clokie and Robinson, above n 3, v.

14 For example, as Dibelius has said of the British commissions, 'the statesman who nominates the commission can almost always determine the course that it is going to take, since he will have a pretty good knowledge beforehand of the minds of the experts whom he puts on it, while, of course, avoiding any appearance of "packing his team"', cited in Martin Bulmer, 'Introduction' in Martin Bulmer (ed), Social Research and Royal Commissions (Routledge, 2015) 3. 
Further, royal commissions weave in and out of the space commonly occupied by the courts. In conducting their inquiries, royal commissions obtain evidence, issue subpoenas for production of documents and witnesses, cross-examine witnesses and determine conflicting matters of fact using legal method. ${ }^{15}$ They sit in tribunals and courtrooms, often emulating the ceremonies of justice typically seen in those spaces, and are frequently presided over by members of the legal profession, including sitting judges. ${ }^{16}$ As the joint judgment of the High Court reflected in the Hindmarsh Island case: ${ }^{17}$

A judge who conducts a Royal Commission may have a close working connection with the Executive Government yet will be required to act judicially in finding facts and applying the law and will deliver a report according to the judge's own conscience without regard to the wishes or advice of the Executive Government except where those wishes or advice are given by way of submission for the judge's independent evaluation.

Similarly, while the findings of royal commissions are not binding, they have been elevated in government and academic discourse to the status of judicial precedent. ${ }^{18}$ At the same time, the royal commission has been described as the 'ideal Senate' or as akin to Question Hour in the British Parliament. ${ }^{19}$

The Australian royal commission is also attended by the complexities of intergovernmental interaction and cooperative federalism. Fourteen joint commissions, commenced by separate letters patent issued by the Commonwealth and Australian states and territories have enabled major inquiries to occur in relation to subject matters extending across federal

15 As Cowlishaw writes in relation to the Royal Commission into Aboriginal Deaths in Custody, for example, 'the practices of the legal profession naturally dominated the proceedings ... Legal enquiry operates in terms of certain principles. "The truth" or "the facts" is supposed to emerge from the presentation of evidence and questioning of witnesses in an adversarial context'. See further, Cowlishaw, above n 3, 32-5.

16 See further, Fiona Wheeler 'Anomalous Occurrences in Unusual Circumstances? Towards a History of Extra-Judicial Activity by High Court Justices' (Speech delivered to the High Court of Australia Public Lecture Series, Canberra, High Court of Australia, 30 November 2011).

17 Which considered, among other things, the appointment of a Federal Court judge to conduct an inquiry under the Aboriginal and Torres Strait Islander Heritage Protection Act 1984 (Cth); see Wilson $v$ Minister for Aboriginal \& Torres Strait Islander Affairs (1996) 189 CLR 1, 17. See further, Fiona Wheeler, 'The Use of Federal Judges to Discharge Executive Functions: The Justice Matthews Case' (1996) 11 AIAL Forum 1.

18 Hallet, above n 10, 4.

19 Clokie and Robinson, above n 3, 6-7. 
and state spheres of power. ${ }^{20}$ For example, the Royal Commission into Aboriginal Deaths in Custody (RCIADIC), the Royal Commission on Human Relationships (Human Relationships RC), the Royal Commission into the (organised crime) activities of the Federated Ship Painters and Dockers Union (Painters and Dockers RC) and the Royal Commission into Institutional Responses to Child Sexual Abuse (Child Abuse RC) are the products of letters patent issued by multiple Australian governments. We return to the archives of these important commissions in greater detail below.

While the royal commission may reflect a constitutional struggle to confine royal action to 'certain modes of procedure', this mode, we suggest, is multifaceted and spans the gamut of governmental action.

\section{Social and Cultural Functions of Royal Commission Inquiries}

The inquiries of royal commissions also have a complicated social and cultural function and identity. First, modern royal commissions are commonly elaborate public events. Their core processes are premised on active participation by citizens in political life and democracy, beyond obedience of laws (or the burden of sanctions for their breach) and electoral voting.

As Bulmer has described, 'making invitations to submit evidence; receiving written evidence; holding public hearings at which oral evidence is presented; and making visits of inspection relevant to their subject' lie at the heart of the royal commission's processes. ${ }^{21}$ 'The public' are invited in, often literally by published invitations in newspapers and online. The spaces in which they sit are designed for public participation, as witnesses of the commission and in the public galleries. In this sense, royal commissions are sites for active citizenship ${ }^{22}$ on issues of civil

20 Stephen Donaghue, Royal Commissions and Permanent Commission of Inquiry (Butterworths, 2001) 5 .

21 Bulmer, above n 14, 2-3.

22 See further, Kim Rubenstein, Australian Citizenship Law in Context (Lawbook Co, 2002) ch 3; Barry Sullivan, 'FOIA and the First Amendment: Representative Democracy and the People's Elusive "Right to Know"' (2012) 72(1) Maryland Law Review 1, 24-6; TJ Cartwright, Royal Commissions and Departmental Committees in Britain: A Case-Study in Institutional Adaptiveness and Public Participation in Government (Hodder and Stoughton, 1975). 
importance. As Elizabeth Evatt AC recently reflected in relation to the Human Relationships RC, in which she, Anne Deveson and Felix Arnott were appointed commissioners:

The success of the royal commission was largely due to Anne's insistence that we take the inquiry out to the people. We did this by holding open hearings and meetings in many places throughout Australia in an attempt to hear the voices of as many Australians as we could. The resulting report is enriched by the words of the people who spoke to us. ${ }^{23}$

Second, royal commissions have very often established a direct line of communication to the public during the life of the inquiry, culminating in the publication of their final report. Since at least the early 2000s, most royal commissions have created large websites, which, during the period of the commission, variously provide access to live and archived streams of evidence, transcripts of proceedings, narratives of selected private evidence read by actors ${ }^{24}$ and messages from the relevant commission asking for assistance. Previously, evidence of commissions has been broadcast or provided daily to media through briefing summaries. ${ }^{25}$ Hearings have also been largely public events, at least until specific reforms enacted for the taking of private testimony regarding child sexual abuse. In the British historical context, edited serials of the transcripts of each day of evidence were published and distributed. ${ }^{26}$ Further, in the context of the Child Abuse RC, a single copy of a book containing 'Messages to Australia' from a select number of survivors was published and deposited with the National Library of Australia when this royal commission concluded in December 2017. ${ }^{27}$

23 Elizabeth Evatt, cited in Wendy McCarthy, 'Anne Deveson, a warrior for thoughtful, social change', Sydney Morning Herald (online) 13 December 2016 <http://www.smh.com.au/comment/ obituaries/anne-deveson-a-warrior-for-thoughtful-social-change-20161213-gt9wkr.html>.

24 See Royal Commission into Institutional Responses to Child Sexual Abuse, Narratives (n.d.) $<$ https://www.childabuseroyalcommission.gov.au/narratives $>$.

25 Departmental Committee on the Procedure of Royal Commissions, Report of the Departmental Committee on the Procedure of Royal Commissions (The Stationery Office, 1910), [12].

26 See, for example, United Kingdom, Royal Commission on Public Records, Minutes of Evidence (House of Commons, 1912-13).

27 Royal Commission into Institutional Responses to Child Sexual Abuse, Message to Australia (n.d.) $<$ https://www.childabuseroyalcommission.gov.au/message-australia $>$. 
In this way, as sociologist Katie Wright argues, the effects of royal commissions may be 'multi-layered, as much social and cultural as they are political and practical'. ${ }^{28}$ In her view, their inquiries:

throw into sharp relief issues of major social concern: they are symbolic of an open and transparent society 'where the voices of the powerless are heard' and the powerful are held accountable, and importantly, they increasingly provide a cathartic function for victims/survivors and indeed for societies more broadly. ${ }^{29}$

In a related way, the capacities of a royal commission to reshape social norms are evident. For example, in relation to the Canadian Royal Commission on New Reproductive Technologies, Weir and Habib argue that:

Some of the resulting statements defining women's interests, such as those made by Aboriginal women's organizations, were unprecedented anywhere. Hence, the process of participating in the Royal Commission also led to the dissemination of new dialogic positions. A state inquiry was thus the eliciting condition for the development of knowledge by a social movement about changes in scientific knowledge. ${ }^{30}$

At the same time, the royal commission is a powerful instrument of governance and knowledge production. While they may create opportunities for a multiplicity of views to be heard or for the interrogation of hostile witnesses, through their curated websites, daily press summaries, lines of inquiry and reporting, they also produce-from a vast mass of information-powerful narratives and official knowledge for public consumption and endorsement. ${ }^{31}$ As Clokie and Robinson observed of the broadcasts of evidence made by royal commissions through the 1960s in Britain, the royal commission serves the 'great Benthamite principle of government, namely publicity', including drawing the public into government and consolidating public support for the legal outcomes of the commission. ${ }^{32}$ Similarly, the commission

28 Katie Wright, 'Childhood, Public Inquiries and Late Modernity' in B West (ed), Challenging Identities, Institutions and Communities, Refereed Conference Proceedings of the Australian Sociological Association Conference (University of South Australia, 2014) 5.

29 Ibid 4.

30 Lorna Weir and Jasmin Habib, 'A Critical Feminist Analysis of the Final Report of the Royal Commission on New Reproductive Technologies' (1997) 52 (Spring) Studies in Political Economy $137,148$.

31 Charles J Hanser, Guide to Decision: The Royal Commission (Bedminster Press, 1965) ix.

32 Clokie and Robinson, above n 3, 139-40, 177. 
has been described as promoting social control by government; ${ }^{33}$ as an ideological crisis management strategy; ${ }^{34}$ and as a tool in the resolution of public controversy and promotion of public consensus about key issues. ${ }^{35}$

It must also be accepted that in the process of eliciting and announcing public truths, some voices and narratives may not be heard, or indeed may be silenced, by royal commissions. Even in the context of the Canadian Reproductive Technologies Royal Commission referred to above, some forms of knowledge assumed an untouchable position. For example, Weir and Habib have illustrated the privileging of 'biomedical visions' of the body at the expense of understanding or hearing feminist voices in relation to the 'social and cultural changes associated with the government of human reproduction'. ${ }^{36}$ By 'proceeding from a binary distinction between nature and culture', the commission elided any 'notion that expertise could in any way be constitutive of the body' and failed to:

heed the warning in a number of feminist briefs to the royal commission, particularly those from Quebecois feminists, which broke the Commission's biomedical and legal framing of issues in order to argue that the discourse of new reproductive technologies is especially dangerous because it assimilates women's activity in having children with men's. ${ }^{37}$

Similar issues have arisen in the context of Australian royal commissions. As Purdy has forcefully argued in relation to the RCIADIC's findings:

practices and rules of law combined to create a space in which legal discourse in the form of judgments and reports can be constructed. This space is created not only by the determination of who will be able to speak and what they will be allowed to say ... but also who will be able and prepared to speak, and what they will be prepared to say. ${ }^{38}$

33 Hanser, above n 31, 160; see also, Geoffrey Lindell, 'British Tribunals of Inquiry: Legislative and Judicial Control of the Inquisitorial Process: Relevance to Australian Royal Commissions' in Research Paper No 5 (Department of the Parliamentary Library, Australia, 15 April 2003) 6.

34 George Gilligan, 'Royal Commissions of Inquiry' (2002) 35(3) Australian and New Zealand Journal of Criminology 289, 289-90.

35 Scott Prasser, 'Royal Commissions and Public Inquiries: Scope and Uses' in Patrick Weller (ed), Royal Commissions and the Making of Public Policy (MacMillan Education, 1994) 6-8.

36 Weir and Habib, above n 30, 151.

37 Ibid 151.

38 Purdy, above n 3, 33. 
As an employee of the RCIADIC, Cowlishaw, too, has described a coalescence of factors that resulted in circumstances where it 'rarely had direct evidence other than from police and prison wardens' ${ }^{39}$ As she argues:

neither in the legal process, the scientific discourse of experts, nor in the welfare framework of the socially concerned was there much room for Aboriginal voices, and certainly a radically different framework of discussion could not be accommodated. ${ }^{40}$

Moreover, Cowlishaw demonstrates how, together, the commission's terms of reference and legal method privileged attention to a dogged but largely elusive pursuit of 'culprits' for the deaths of the particular people in question, at the expense of attention to subtler, more difficult social processes contributing to Aboriginal incarceration and deaths in custody. In the legal process, she writes, 'there is little room for recognising that a particular kind of account of events is being created, and another kind excluded'. ${ }^{41}$ Rather, for example, while the RCIADIC 'sought out anyone who might be able to give evidence, perused police daybooks and worksheets, calculated times and distances, and examined fingerprints as in the most careful murder investigation', ${ }^{42}$ swearing, for example, was erased from accounts of the interaction between police and Aboriginal people despite the centrality of abusive swearing to police-Aboriginal relations and, potentially, the incarceration of Aboriginal people. ${ }^{43}$

39 Cowlishaw, above n 3, 30.

40 Ibid 36. She describes insufficient funding to key Indigenous rights advocacy bodies that had been tasked to investigate issues underlying the deaths under inquiry, alienation of Aboriginal people from the commission's processes, a reluctance to give evidence by prisoners based on fear of reprisal and severe limitations on the utility of evidence given by prisoners in relation to historical deaths in circumstances where they had not been interviewed at the time of death. Amy McQuire argued, further, that the voices of Aboriginal women were 'completely drowned out'. See Amy McQuire, 'Black Women, And A Tale Of Two Commissions' New Matilda (online) 15 April 2016 < https://newmatilda.com/2016/04/15/atale-of-two-royal-commissions/ $>$. The RCIADIC is not the only Australian royal commission in which legal processes have been applied to Aboriginal people's experiences with the effect of 'believing' and 'valuing' certain voices, nor in which the voices of certain Aboriginal people have been absent. See, in relation to the Hindmarsh Bridge (South Australian) Royal Commission, Joanna Bourke, 'Women's Business: Sex, Secrets and the Hindmarsh Island Affair' (1997) 20(2) UNSW Law Journal 333. See, in relation to royal commissions more broadly, Steve Hemming and Daryle Rigney, 'Decentring the New Protectors: Transforming Aboriginal Heritage in South Australia' in Emma Waterton and Steve Watson (eds), Heritage and Community Engagement: Collaboration or Contestation? (Routledge, 2013) 100-14. Hemming and Rigney write at 104 that 'Legislation, royal commissions, court cases and other legal spaces play an ongoing role in constructing and authenticating histories and stories of Indigenous culture. In this context, the colonial archive is both activated and reinvigorated, and new elements and interpretations are introduced'.

41 Cowlishaw, above n 3, 33.

42 Ibid 31.

43 Ibid 34. 
Therefore, royal commissions are undeniably poised in a delicate relationship of trust between citizen and government. ${ }^{44}$ While their letters patent compel the commissioners to inquire into certain matters and advise the Crown, the royal commission also powerfully recalibrates or affirms social norms, rearticulates or further embeds dominant discourses and amplifies or placates the anxieties of members of the community. As we argue below, the royal commission's social and cultural identity and effects compel attention to the archives of these complex bodies.

\section{Royal Commission as Archive}

As a result of their functions — both institutional and sociocultural-royal commissions hold vast archives of important historical material. However, unlike courts or government departments, once the royal commission ends, it ceases to exist. In practice (and at law), then, questions of access, care and responsibility in respect of its records leave the 'commission as inquiry' behind, to be answered, often incompletely, by agencies who take, or are left with, responsibility for the commission's archive.

There remains a dearth of attention to the practical and theoretical issues attending royal commission archives. Indeed, when the Australian Law Reform Commission considered the arrangements for royal commission records in 2007, it noted that it had 'received limited feedback from stakeholders regarding issues of access and use of documents or things collected by completed Royal Commissions or other public inquiries' ${ }^{45}$

As we illustrate below, access, care and responsibility for these records are, often, adrift between multiple legislative regimes, which prejudices their public availability and promotion, as well as the integrity of the archive itself. However, before doing so, it is necessary to conceive of 'the royal commission as archive' and to identify the risks, stakes and imperatives for civil society, public accountability, transparency and governance posed by these volumes of material.

44 Dara M Price and Johanna J Smith, 'The Trust Continuum in the Information Age' (2011) 11 Archival Science 253, 266.

45 Australian Law Reform Commission, Royal Commissions and Official Inquiries, Discussion Paper No 75 (2007), [8.47]. 


\section{The Royal Commission as Archive?}

The documentary record of a royal commission cannot be conceived of as mere residue, pressed into obscurity by the primacy of the commission's final report and the fulfilment of its terms of reference. Rather, the royal commission's archive must be treated as a powerful and important product of government in its own right. While it may be correct that 'there seems to be little consensus as to what an archive is ${ }^{,}{ }^{46}$ in describing the archives of the royal commission here, we seek to speak of the totality of material held by the institution before its cessation, including the transcripts of evidence, commissioner's notes, documents produced to, or seized by, an inquiry, investigative records and the administrative records of the commission regarding its own operation. ${ }^{47}$ In this sense, as we discuss below, it is an archive - the 'official record' of the commission ${ }^{48}$ - but also a body of material, which may have a life of its own after the commission's terms of reference are fulfilled. This is so in three key respects.

\section{Royal Commission Archives as Key to Executing its Functions}

First, the vast archives of royal commissions are a substantial product of the inquiry process. Inasmuch as the inquiry process may have invited or coerced individuals and institutions to provide it with information, it is the total record of its work, and not necessarily the report, that retains the information it has elicited. Clearly, in this way, the archive has 'obvious informational value' ${ }^{49}$ and is integral to taking action on the basis of that information. For example, the Australian Law Reform Commission has highlighted the critical importance of royal commission records for law enforcement, implementing inquiry recommendations and advising on the administration of laws. ${ }^{50}$ It is an archive in the sense described by Ridener as a 'place for the uncovering of records which are not duplicated in any other [single] place'. ${ }^{51}$ The importance of the archive here is

46 Spieker Sven, The Big Archive: Art from Bureaucracy (MIT Press, 2008) 4.

47 Developing a conception of the archive in this way has been a central goal of the Court as Archive Project, undertaken by the editors of this text. Both authors acknowledge the work of the project in foregrounding attention to the archives of institutions in this way.

48 For further discussion of the multiple meanings of 'the archive' in connection with legal processes, see Katherine Biber and Trish Luker, 'Evidence and the Archive: Ethics, Aesthetics and Emotion' (2014) 40(1) Australian Feminist Law Journal 1, 5-11.

49 Price and Smith, above n 44.

50 Australian Law Reform Commission, above n 45, [8.47].

51 John Ridener, From Polders to Postmodernism: A Concise History of Archival Theory (Litwin Books, 2008) 4 . 
straightforward: it provides for direct action on the information gathered by the commission towards the purposes for which it was established. Similarly, especially in the case of commissions that have uncovered harm to individuals, the particular records of this evidence are vital for individuals who may seek to pursue civil or coronial proceedings.

As a body of evidence, too, the records created by the commission may arguably represent the key product of a royal commission's processes. As Price and Smith write of Canadian royal commissions (referring here to the Indian Specific Claims Commission [ISCC]):

In light of the fact that the ISCC had no real legislative or adjudicative power, the records represent the key product of the process, and the most important means by which it could exert moral influence in society. The raison d'etre of the Inquiry becomes the collection, collation and preservation of a permanent, coherent body of evidence. ${ }^{52}$

\section{Royal Commission Archives as an Accountability and Critique Mechanism}

Second, prioritising and thinking consciously about the royal commission as archive is critical to allowing for critique of the commission's governmental, social and cultural functions. Given the delicate relationship of trust between the institution of the commission and the public outlined above, its records may form, at the very least, 'evidence that the government has [or has not] carried out its responsibilities to society' ${ }^{53}$ and an 'audit trail', which may reveal 'evidence of negligence, malfeasance and missteps'. ${ }^{54}$ In this sense, the archive is an accountability mechanism providing an 'official record' against which the technical strength and cogency of the commission's findings and recommendations may be assessed. ${ }^{55}$

\footnotetext{
52 Price and Smith, above n 44, 270.

53 Ibid 265.

54 Ibid 266.

55 The archive here may arguably provide a continued honouring of the active engagement sought by the commission as inquiry between 'active citizens' and government. For example, Barry Sullivan (citing James Madison) has argued that 'the right to know' is a fundamental tenet of a model of representative democracy, which expects engagement by citizens with the architecture of government. See Sullivan, above n 22, 35.
} 
Moreover, as cultural theorists, archivists and (now) legal scholars ${ }^{56}$ argue, the ability to interrogate the form and context of state archives, in addition to its content, provides opportunities for critical engagement with the power relations inherent in its production, and of state power. As Steedman has written, 'in its quiet folders and bundles is the neatest demonstration of how state power has operated, through ledgers and lists and indictments, and through what is missing from them'. ${ }^{57}$

In this context, we are concerned not just with the content of information acquired by the commission, but also with information created by it. This includes the records of its own administration, its operational decisions and evidence of the way it has curated its public presence and shaped its priorities. At a deeper level, it includes the totality of the record and what it may implicitly reveal about the commission as an instrument of governance; the construction and resolution of the issues under its remit; and the things it silences and privileges. In this sense, the archive is the site at which to read, for example, 'what can be said' before a commission ${ }^{58}$ and what cannot, and the ways in which knowledge, semantics and the legal method may elevate certain evidence, or diminish or disempower others during its operation. ${ }^{59}$ In addition, as Stoler makes clear, attention to the 'surplus production' of state archives - the marginalia, edits and footnotes, handwritten drafts and the contradiction between official and unofficial records-may open up new reflections on the psychic state of the empire. ${ }^{60}$

Importantly, the royal commission as archive is a site for disturbing, potentially, the 'coherence' of the official record and its intended 'moral influence' (as referred to by Price and Smith, cited above). It is an opportunity to critique the state and the commission, and to see more

56 See, for example, the emerging literature in relation to 'law's archive' captured in a special issue (2014) 40(1) Australian Feminist Law Journal.

57 Carolyn Steedman, Dust: The Archive and Cultural History (Manchester University Press, 2001) 68.

58 As van Rijswijk writes, for Foucault, the archive is not just 'that whole mass of texts that belong to a single discursive [in this case legal formation]', but should also be thought of as the 'law of what can be said, the system that governs the appearance of statements'; see Honni van Rijswijk, 'Archiving the Northern Territory Intervention in Law and in the Literary Counter-Imaginary' (2014) 40(1) Australian Feminist Law Journal 117, 119.

59 Rebecca Monson, 'Unsettled Explorations of Law's Archives: The Allure and Anxiety of Solomon Islands' Court Records' (2014) 40(1) Australian Feminist Law Journal 35, 39.

60 Ann Laura Stoler, 'Colonial Archives and the Arts of Governance' (2002) 2 Archival Science 87; Ann Laura Stoler, Along the Archival Grain: Epistemic Anxieties and Colonial Common Sense (Princeton University Press, 2009) 41. 
clearly the interaction between those who govern and are governed. It is a place to read what is missing (eg, the omission of swearing from the accounts of police-state interaction, witnessed by Cowlishaw during the RCIADIC) and, potentially, ${ }^{61}$ to uncover traces of alternative narratives.

\section{Royal Commission Archives as Social, Public Memory}

Third, the collected records of royal commissions are undeniably significant repositories of public memory. In collecting together previously untold life stories, investigations of institutional actions, narratives of the interaction between the state and its citizens, corruption, corporate failures and other matters of national importance, the records of royal commissions provide a 'vital aspect of the social memory of modern societies' ${ }^{62}$ In particular, in the minutiae of the documents created during an inquiry, the royal commission archive is a record not just of public decisions and the formation of public policy, but also of 'information about how public laws and regulations and public institutions affect individual citizens in various aspects of their lives'. ${ }^{63}$ For example, as Cowlishaw observed of the public material she viewed during the conduct of the RCIADIC (and which is now, as we discuss below, subject to a complex legislative access scheme), 'the vast array of files reveals the levels of monitoring and surveillance, which Aboriginals [sic] have been subjected to, and attests to the fact that they have not been authorised to produce their own accounts of their experiences. ${ }^{64}$

61 Accepting that there are strong critiques of an uncritical approach of 'going back to the archives' to 'produce a more correct account'. See further, Victoria Brown 'Explorations in Feminist Historiography: Rhetoric, Affect and "What Really Happened" in Feminism's Recent Past' (2014) 7(2) Subjectivity 210, 212.

62 Inge Bundsgaard, 'The Question of Access: The Right to Social Memory versus the Right to Social Oblivion' in Francis X Blouin Jr and William G Rosenberg (eds), Archives, Documentation, and Institutions of Social Memory (University of Michigan Press, 2006) 114.

63 Blouin Jr and Rosenberg, above n 62, 114.

64 Cowlishaw, above n 3, 33; see also, for example, the use of inquiry transcripts (in this case, a parliamentary inquiry, rather than a royal commission) in the 'Minutes of Evidence Project', which aimed to 'spark ... conversations about history and structural justice through the professional performance of transcripts of evidence given before the 1881 Victorian Parliamentary Coranderrk Inquiry'. See further, Minutes of Evidence Project, Performance: We Will Show the Country (n.d.) $<$ http://www.minutesofevidence.com.au/performance/>. 


\section{Dislocation, Absence and Complexity in Locating and Accessing the Commission as Archive}

The existing scheme for managing the records of royal commissions does not understand these records as a single archival resource and relies heavily on ad hoc executive action-be it ministerial direction, ministerial approval to 'special access' or intergovernmental agreement- to supply the content of custody and access arrangements. As we suggest below, this dislocated regulatory approach undermines both the integrity of the royal commission archive and the capacity of the royal commission to fulfil its functions and create meaningful public records.

The legislative difficulty in regulating records of royal commissions (whether of single or joint jurisdictional character) is in part a product of the unique nature of royal commissions as entities. Although an executive entity during the term of an inquiry, a royal commission ceases to exist in law once the period provided for in its establishing letters patent lapses (without being extended by issue of subsequent or amending letters patent). Thus, given absent specific legislative provision, complex questions can arise as to the ownership of royal commission records once a commission ends.

\section{Joint Commonwealth and State/Territory Royal Commissions}

The complexities attending access to royal commission records in this respect are most acute in the context of joint royal commissions. Such commissions are the necessary institutional structure where the Commonwealth seeks to inquire into matters that wholly or partly fall outside the scope of Commonwealth legislative power. ${ }^{65}$ They may also be the preferred institutional structure-though one strictly unnecessary, as a matter of constitutional power-where the governments of more than one Australian jurisdiction seek to inquire into a subject matter within Commonwealth legislative power, but in which the states have some interest. To enable joint royal commissions to coercively obtain

65 Within the terms of s 51 of the Australian Constitution. 
information and documents across territorial boundaries, the relevant inquiring institution is typically conferred with evidence-gathering powers under the statutes of each participating jurisdiction. ${ }^{66}$

In the context of these royal commissions, where material is received and produced during the course of an inquiry, records within the archive may be of multifaceted jurisdictional character. Is a document produced under summons issued in reliance on more than one coercive power (ie, under legislation of more than one participating jurisdiction ${ }^{67}$ a document of the jurisdiction in which it was produced, a document of the jurisdiction in which the summons was served or a document of both state and federal character? Similarly, is a document produced by a commission sitting as a state and federal commission a state, Commonwealth or state and Commonwealth document?

The existing legal apparatus to meet such complexity is presently also multifaceted and, we argue, unresolved. As we detail below, further complexity attends the custody and access to records of joint royal commissions, but also commissions commenced by a single government.

\section{Custody, Possession and Use of Commonwealth and Joint Commonwealth and State/Territory Royal Commission Records}

Although each Australian jurisdiction has enacted legislation providing for the exercise of coercive powers by joint royal commissions, these legislative schemes operate incompletely in their treatment of records produced by such inquiries once the relevant inquiry ends. Only the Inquiries Act 2014 (Vic) makes express provision for the treatment of records of state

66 Royal Commissions Act 1923 (NSW), s 8; Commissions of Inquiry Act 1950 (Qld), s 5; Royal Commissions Act 1917 (SA), s 10; Commissions of Inquiry Act 1995 (Tas), s 22; Inquiries Act 2014 (Vic), s 17 (read with s 7); Royal Commissions Act 1968 (WA), s 9; read with ss 2 and 7AA of the Royal Commissions Act 1902 (Cth).

67 See, for example, Re Winneke; ex Parte Gallagher (1982) 152 CLR 211, concerning a summons issued in reliance on the Royal Commissions Act 1902 (Cth) and the Evidence Act 1958 (Vic) (which, at that time, governed the powers exercisable by state commissions). The question of how documents were produced in response to a summons with dual jurisdictional character was not answered by the High Court. 
commissions to which that Act applies. ${ }^{68}$ Other state jurisdictions merely treat royal commission records as any other document of an executive body, subject to state public archives legislation, but not differentiated in their treatment (for custody, possession, use and access purposes). ${ }^{69}$

This characterisation becomes important when considering the application of the archives provisions of the Royal Commissions Act 1902 (Cth) and the Archives Act 1983 (Cth) ('Archives Act'). Overlaying the idiosyncratic state royal commissions regimes, the Royal Commissions Act 1902 (Cth) and Archives Act make specific provision, albeit incompletely, for the treatment of the records of joint royal commissions.

Section 9(2) of the Royal Commissions Act 1902 (Cth) provides for the making of regulations for the custody in which some or all of the records of a Commonwealth royal commission ${ }^{70}$ are to be kept. Such regulations may also provide for the purposes for which relevant records may and must not be used, ${ }^{71}$ as well as the circumstances in which a custodian ${ }^{72}$ of royal commission records must give possession of, or access to, those records to other persons or bodies. ${ }^{73}$

Section 9(3) prescribes the persons and bodies who may be given custody of royal commission records by regulations made under s 9(2). All of the prescribed custodians are Commonwealth institutions, save for two: state Attorneys-General and state law enforcement bodies. That the Act provides for state custodians of royal commission records is relevant to the discussion below of the access regime prescribed by the Archives Act. This is because where regulations are made for the purposes of $s 9(2)$ of

68 The Commissions of Inquiry Act 1950 (Qld) does empower the commissioner of a relevant inquiry to make directions as to the custody of records while a commission is on foot, but is otherwise silent on what is to happen once a commission ends: s $19 \mathrm{~B}(2)$.

69 See, for example, State Records Act 1998 (NSW), s 3(1)(i) (definition of 'public office'), which includes a 'Royal Commission or Commission of Inquiry'; and s 7(4A), which provides, relevantly, that the records of a public office that has ceased to exist, and which was a royal commission or commission of inquiry, are to be subject to the control of the Cabinet Office. See also the various record-keeping obligations of 'public offices', as defined: State Records Act, ss 11-15, 21-25 and 26-36A.

70 See s 1B(1) definition of 'Royal Commission'.

71 Section 9(2)(b), (e); see also s 9(6), (7).

72 Section 9(3) prescribes the persons and bodies who may be given custody of records by regulations made under $s 9(2)$.

73 Section $9(2)(\mathrm{c}),(\mathrm{d})$. 
the Royal Commissions Act 1902 (Cth), the Archives Act has effect as if a direction to the same effect were in force under s 22(3) of that Act. ${ }^{74}$ In any event, it is worth noting that regulations for the purposes of s 9(2) have only been made in the context of two previous commissions. ${ }^{75}$

The Archives Act extensively prescribes the circumstances in which a 'Commonwealth record' is to be dealt with and accessed. ${ }^{76}$ A 'Commonwealth record' is defined as a record that is either the 'property of the Commonwealth or of a Commonwealth institution' or a record that is deemed to be a Commonwealth record by operation of $s 22 .{ }^{77}$ Royal commission records fall outside the ordinary definition of 'Commonwealth record', given that there is no legal entity in possession of relevant records once a commission ends. However, s 22(2) of the Archives Act deems records kept by a royal commission (defined, relevantly, as a Commonwealth royal commission $)^{78}$ to be 'Commonwealth records' for the purposes of the Act and provides that the Commonwealth is entitled to the possession of such records once they are no longer required for the purposes of a commission.

Section 22(3) requires that deemed Commonwealth records be kept in such custody as the relevant responsible Commonwealth Minister directs and the National Archives of Australia (NAA) is not entitled to the 'care' of such records except in accordance with such a direction. ${ }^{79}$ As the Australian Law Reform Commission has observed, the effect of s 22(3) is that there is no legal requirement for records of royal commissions to be

\footnotetext{
74 Section 9(5).

75 The Royal Commission into Trade Union Governance and Corruption and the Oil-for-Food Inquiry: Royal Commissions Regulations 2001 (Cth), regs 8 and 9. A separate regulatory regime was enacted to provide for the transfer of certain records of the HIH Royal Commission (which was not a joint commission) to the Australian Securities and Investment Commission: HIH Royal Commission (Transfer of Records) Act 2003 (Cth); HIH Royal Commission (Transfer of Records) Regulations 2003 (Cth).

76 Pt V, divs 3 and 4.

77 Archives Act, s 3(1). The definition excludes certain presently irrelevant material.

78 Being the records kept by a royal commission commenced or completed before or after the commencement of Part V of the Archives Act, s 22(1).

79 Section 22(3).
} 
transferred to the NAA..$^{80}$ The authors suggest that this lack of obligation to transfer royal commission records to the NAA, coupled with the potential in the existing legislative context for the records of a royal commission to be in the custody or possession of multiple Commonwealth and state agencies, undermines the integrity of such records as archival resources. This problem is exacerbated by the complex regime governing access to the records of joint royal commissions, considered further below.

\section{Access to Royal Commission Records- Commonwealth and Joint Commonwealth and State/Territory}

Royal commission records to which the Archives Act applies are subject to the ordinary open access periods prescribed by that Act, ${ }^{81}$ save in the case of certain records relating to 'private sessions' of the Child Abuse RC. ${ }^{82}$ It is important to consider the practical implications of this statement. First, the import of this rule is that many of a royal commission's records that were public during the life of the commission (eg, public submissions, transcripts of public hearings and other material hosted on the commission website, if it is not maintained online) cease to be public before the open access period is reached. Except in the case of Cabinet notebooks or recordings containing Census information, the open access period commences 31 years after the date the document was created. Second, in order to be subject to the Archives Act and the open access period, a record must be a Commonwealth record: a status that is by no means clear in relation to the records of joint royal commissions.

80 Australian Law Reform Commission, Making Inquiries: A New Statutory Framework, Report No 111 (2009), [8.47-8.48] ('Making Inquiries'). Section 27 of the Archives Act prescribes a time frame for transfer of certain 'Commonwealth records' to the NAA; however, that provision is unlikely to apply to royal commission records. Section 27 only applies to a record that is in the custody of a Commonwealth institution other than the NAA (s 27(1)(a)) and that has been determined to be part of the archival resources of the Commonwealth under s 3C (s 27(1)(b)). It would seem to subvert the clear legislative intention of $s 22$ (namely, that royal commission records be dealt with under a regime separate to that applying to ordinary Commonwealth records) if the Director-General could make a direction under s $3 \mathrm{C}$ that, of its own force, had the effect of bringing royal commission records within the operation of s 27 and, thus, circumventing the operation of s 22 (which, critically, provides that the responsible Minister is the only decision-maker who can determine that royal commission records be transferred to the NAA). In our view, this regime is very likely to engage the principle in Anthony Horden \& Sons Ltd v Amalgamated Clothing and Allied Trades Union of Australia (1932) 47 CLR 1, 7. In any event, $s 27$ would not apply to records of joint royal commissions, given that the provision only applies to Commonwealth records (that meet the requirements of s 27 (a) and (b)).

81 Archives Act, pt V and definition of 'open access period' (s 3(1)(c) and (7)).

82 Royal Commissions Act 1902 (Cth), s 6OM. 
Records that are in the open access period and in the care of the NAA or the custody of a Commonwealth institution (and which are not otherwise exempt) ${ }^{83}$ are required to be made publicly available. Any non-publication direction given by a royal commission in respect of such records (necessarily during the life of a commission) ceases to apply once the records enter the open access period. ${ }^{84}$

Access to royal commission records may be provided under the Freedom of Information Act 1982 (Cth), subject to the limitations of that Act; however, this may only occur while the relevant record is not in the open access period. ${ }^{85}$ Access may also be provided outside of the open access period where 'special access' is granted by the responsible Minister, in accordance with arrangements approved by the Prime Minister. ${ }^{86}$ However, 'special access' may only be granted in respect of royal commission records deemed to be Commonwealth records by operation s 22 of the Archives Act.

In the context of joint commissions, a greater impediment to access is s 22(6), which provides that the deeming and custody provisions of s 22(2) and (3) only apply to joint royal commissions to the extent determined by agreement between the Commonwealth and the relevant participating state(s). Neither the Archives Act nor the Royal Commissions Act 1902 (Cth) supply the content to arrangements made by the Commonwealth and the states for the purposes of s 22(6) and such arrangements are not required to be tabled in Parliament, gazetted or otherwise published publicly. Practice also suggests that such arrangements may not be finalised until a royal commission is approaching its effluxion date or may not be made at all.

Before turning to consider difficulties of access in practice, one further point of note is that records of Commonwealth royal commissions that are in the custody of a state custodian (ie, a state Attorney-General or a state law enforcement agency) would seem not to be subject to the access obligations in the Archives Act and may not be subject to the access obligations contained in state public records legislation. ${ }^{87}$ As will be

83 As to which, see ss 29,33 and 35.

84 Archives Act, s 22(4).

85 Freedom of Information Act 1982 (Cth), ss 12(1) and 13(3).

86 Archives Act, s 56(1).

87 For example, records received by the Attorney-General of Victoria or Victoria Police would seem not to meet the definition of 'public record' for the purposes of the Public Records Act 1973 (Vic): see the s 2(1) definitions of 'public record' (para (a)), 'public officer' and 'public office'. 
suggested later, legislative gaps of this sort would best be addressed by a cooperative legislative scheme, supported by referrals of power from the states to the Commonwealth.

\section{Record Movements and the Difficulties of Access in Practice}

Although royal commission records may be transferred to the NAA, the existing legislative scheme does not prescribe a time frame for such transfer. ${ }^{88}$ The absence of such a requirement, combined with the existing scheme's reliance on executive action, gives rise to the real possibility that a commission may end without clear requirements for record management having been in place during the course of its inquiry. In an immediate sense, this creates a risk of records being be disposed of or collated ineffectively by the commission (and subsequent custodians). In the longer term, failure to have arrangements in place for the treatment of records before a relevant inquiry ends leaves those records in an ambiguous legal state, productive of accessibility issues for citizens and administrative burden for participating governments.

Thus, royal commission records often exist in an indeterminate state of partial regulation, formally subject to the Archives Act, but not to substantive arrangements of the kinds contemplated by that Act.

Contact with the NAA and with researchers and practitioners attempting to engage with the work of royal commissions reveals the practical impediments created by such complexities.

\section{Locating the Archive in the Regulatory Penumbra}

The NAA estimates that there are over 100 royal commissions affected by issues arising from the application of ss 22(3) and (6) of the Archives Act. This includes commissions where no direction under s 22(3) was given before the commission ended and joint commissions, of which there are several, for which there are no arrangements in place for the purposes of s 22(6). ${ }^{89}$ The vast majority of these commissions have long since ended.

88 Australian Law Reform Commission, Making Inquiries, at [8.48]. Please see $\mathrm{n} 80$ for the authors' analysis of the relevant provision of the Archives Act.

89 Interview with the staff of the National Archives of Australia (4 September 2017). 
Because the existing scheme does not proscribe the division of collections of royal commission records, when a royal commission ends, its records have often been divided and dispersed. In this respect, the report of the Australian Law Reform Commission Inquiry into Royal Commissions, Making Inquiries: A New Statutory Framework, noted that, as a matter of practice, records concerning the administration of royal commissions (such as internal correspondence) have been transferred to the AttorneyGeneral's Department, while substantive records (such as transcripts, evidence and submissions) have been transferred to the Department of the Prime Minister and Cabinet. ${ }^{90}$ Further, because there is no existing legislative mechanism for automatic transfer of records to the NAA and the Archives Act does not otherwise specify a time frame within which records should be transferred to the NAA, ${ }^{11}$ the existing scheme creates the potential for records to remain indefinitely with a custodial department (be it the Attorney-General's Department or the Department of the Prime Minister and Cabinet).

In the case of commissions for which no s 22(3) direction is given, or no s 22(6) arrangement is agreed, there may be no formal mechanism by which the NAA can grant access to such records. ${ }^{92}$ In the case of commissions for which there are no s 22(6) arrangements in place, the records of those commissions (at least on one argument) may not necessarily be Commonwealth records at all. More broadly, because s 22(6) agreements subject certain records to the legislation of one jurisdiction, ${ }^{93}$ unless an agreement is in place, it may be unclear whether Commonwealth or state legislation properly governs such records. While original records are generally not split across states, in the case of one or two joint commissions, the NAA may hold copies of publicly available material, while a state holds the original documents. ${ }^{94}$ Of course, this will not necessarily mean that an individual's access is straightforward without a s 22(6) arrangement being in place. It appears, too, that some material relating to a royal commission may have been deposited by the Commissioner himself (Frank Costigan QC) with his personal papers at the State Library of Victoria. ${ }^{95}$

90 Making Inquiries [8.48]; see n 80 for the authors' analysis of the relevant provisions of the Archives Act.

91 Ibid.

92 Interview with the staff of National Archives of Australia (4 September 2017).

93 Ibid.

94 Ibid.

95 Francis Xavier Costigan, Papers of Francis Costigan (1968-2009), State Library of Victoria <http://search.slv.vic.gov.au/MAIN:Everything:SLV_VOYAGER2442558>. 
While the NAA endeavours to facilitate access to material of royal commissions affected by ss 22(3) and (6) issues, the NAA has not been able to give access to some of these records. ${ }^{96}$ In the NAA's view, this is a consequence of the inconsistent application of the existing legislative scheme. ${ }^{97}$

Websites recording the work of royal commissions are also not uniformly dealt with. Some are preserved and hosted by the Attorney-General's Department for an indeterminate period of time, although they are generally not preserved in any permanent sense..$^{98}$ Material on commission websites may or may not be selected by the National Library of Australia to go to the PANDORA Archive ${ }^{99}$ or to the Australian Government Web Archive. ${ }^{100}$ However, difficulties abound around how such material, particularly audio and video files, is harvested and may be particularly acute in the context of content-heavy websites, such as royal commission sites. ${ }^{101}$ For example, in its Statement of Preservation Intent on Selective Web Harvesting, the National Library acknowledges the limits of web archiving, including that 'the way in which the content is collected and displayed may mean that there is significant limitation on the presentation of the archived artefact as an authentic record of the publisher's original date'. ${ }^{102}$

\section{Section 22(3) and the Human Relationships RC}

The Human Relationships RC was a joint commission established by the Whitlam Government in 1973 to inquire into and report upon the family, social, educational, legal and sexual aspects of male and female relationships, so far as those matters are relevant to the powers and functions of the Australian Parliament and Government, including powers and functions in relation to the Territories', and to give particular emphasis to

96 Interview with the staff of National Archives of Australia (4 September 2017).

97 Ibid.

98 Making Inquiries, [8.48]. Contrary to the Australian Law Reform Commission's view, websites that it considered 'safe' are no longer accessible and have not been re-archived elsewhere.

99 A web archive established by the National Library of Australia, which is now maintained by the National Library of Australia and 10 other Australian libraries. At least some records of the Royal Commission into HIH Insurance were dealt with in this manner.

100 An initiative of the National Library of Australia, designed to complement the PANDORA Archive.

101 National Library of Australia, Statement of Preservation Intent on Selective Web Harvesting (1 March 2013) <https://www.nla.gov.au/content/preservation-intent-selective-web-harvesting>; see also Paul Koerbin, Report on the Crawl and Harvest of the Whole Australian Web Domain Undertaken during June and July 2005 (10 October 2005), National Library of Australia, <http://pandora.nla.gov. au/documents/domain_harvest_report_public.pdf >.

102 National Library of Australia, above n 101. 
various matters associated with responsible parenting. ${ }^{103}$ A controversial commission, which was ended abruptly following Whitlam's dismissal, the commission's records were transferred to the NAA without a direction under s 22(3) having been made. ${ }^{104}$ In the absence of a s 22(3) direction, the Department of the Prime Minister and Cabinet remains responsible today for determining how access to the records of that commission is given. ${ }^{105}$ The basis for such access would appear to be the 'special access' mechanism in s 56(1) of the Archives Act, the parameters of which are otherwise not prescribed by the Act.

It took sociology researcher Dr Katie Wright over a year to gain access to records of the Human Relationships RC. This was eventually granted as 'special access', although only on the condition that the NAA would be required to examine each record before the material could be used for research. ${ }^{106}$ In obtaining this permission, the researcher was advised that, although the records of the Human Relationships RC are in the open access period and that several records have already been examined for public access (as well as made digitally available on the NAA's website), most of the records are yet to be examined for the purposes of determining whether access to them can be granted. ${ }^{107}$

\section{Section 22(6) and the Child Abuse RC}

The Child Abuse RC, a joint commission of all Australian jurisdictions, concluded its inquiry in December 2017, and is currently the site of contestation and ambiguity with respect to its records. Questions of access are of particular importance to participants in this inquiry, many of whom are survivors of abuse with a direct and profound interest in the commission's work. ${ }^{108}$

103 Australia, Royal Commission on Human Relationships, Final Report (1977), Volume 1, xi.

104 Interview with Dr Katie Wright, La Trobe University (20 January 2017).

105 Ibid.

106 Ibid.

107 Ibid.

108 The Child Abuse RC's own final report noted that easily accessible, high-quality records and record-keeping practices have particular significance for survivors of child sexual abuse: Child Abuse RC, Final Report: Volume 8, Recordkeeping and Information Sharing, 38-40. Justice Coate, writing about her role as a Commissioner of the Child Abuse RC, has also directly detailed the significance of records generally to care leavers and survivors of abuse. See Jennifer Coate, 'Perspectives on Records and Archives: An Update from the Royal Commission' (2017) 45(3) Archives and Manuscripts 237. 
Knowmore, which is a specialist community legal centre that was established to assist survivors of child sexual abuse to engage with the commission's inquiry, anticipates that issues concerning access to the commission's record will, in two respects, be of immediate practical significance for survivors of abuse. ${ }^{109}$ First, access to commission records (particularly transcripts of public hearings) will be important for holding institutions accountable for evidence given to the commission; that is, for verifying that their conduct in response to allegations of abuse is consistent with representations made to the commission about such responses. ${ }^{110}$ Second, access to recordings of private sessions ${ }^{111}$ will be a significant tool for avoiding retraumatising survivors when legal representatives take instructions for the purposes of preparing civil claims or claims under the Commonwealth redress scheme. ${ }^{112}$

Despite discussions between the commission, government and stakeholders in the commission's work that occurred prior to the commission ending, uncertainty remains as to whether, and, if so, how, survivors will be able to access such material now that the commission has ended. For example, it seems likely that the commission's website will remain accessible, although it is unclear whether a systems' administrator will be employed to maintain that material and to ensure that the website's links remain active. ${ }^{113}$ Moreover, prior to the commission ending, no formal arrangements, including for the purposes of $s$ 22(6), had been agreed and no provisions had been put in place for the transfer of records to the NAA or for access to records more generally. ${ }^{114}$

109 Interview with Prue Gregory, Principal Lawyer, Knowmore (29 September 2017).

110 Ibid.

111 In this respect, the Child Abuse RC was the first Commonwealth commission to be empowered by legislation to receive information from witnesses in private session. Amendments made to the Royal Commissions Act 1902 (Cth) by the Royal Commissions Amendment Act 2013 (Cth) made specific provision for how information given at a private session is to be held and used: Royal Commissions Act 1902 (Cth), pt 4, div 2.

112 National Redress Scheme for Institutional Child Sexual Abuse Act 2018 (Cth); see also Royal Commission into Institutional Responses to Child Sexual Abuse, Redress and Civil Litigation Report (2015), <https://www.dss.gov.au/families-and-children/programs-services/children/commonwealthredress-scheme-for-survivors-of-institutional-child-sexual-abuse>.

113 Interview with Prue Gregory, Principal Lawyer, Knowmore (29 September 2017).

114 At the time of writing, the Child Abuse RC's website states only that inquiries concerning access to records should be directed to the Commonwealth Attorney-General's Department. 
The Royal Commissions Act 1902 (Cth) itself also creates access impediments. Relevantly, that Act prescribes that, for the purposes of the Archives Act, records that contain information obtained at a private session or that relate to a private session, and which identify a natural person who appeared at a private session, enter the open access period only 99 years after the relevant record came into existence. ${ }^{115}$ Knowmore already anticipates that it will be important for survivors of abuse to have access to private session material well before the end of the 99-year closed access period. ${ }^{116}$ Survivors may have an interest in accessing both the recording of a private session in which they gave information to the commission and in otherwise knowing what is contained in their private session file. ${ }^{117}$ With respect to the former category of material, in practice, no transcripts of private sessions are available. ${ }^{118}$ Rather, a survivor or their representative has previously been able to seek access to the audio recording of a private session by giving several months' notice to the commission. ${ }^{119}$ Access to such records has been closely supervised by the commission and has typically been provided on the condition that no notes are made of comments made by commissioners, or commission officers, during these sessions. ${ }^{120}$ However, the last date by which requests could be made for access to private session recordings was the end of September 2017, and it remains unclear where these recordings will be held now that the commission has ended. ${ }^{121}$ With respect to original documents given to the commission during a private session, it was anticipated that the commission would attempt to return such documents to the relevant survivor before its inquiry ended. ${ }^{122}$ However, if it was unable to do so in time, such documents will likely be destroyed. ${ }^{123}$

115 Royal Commissions Act 1902 (Cth), s 6OM.

116 Interview with Prue Gregory, Principal Lawyer, Knowmore (29 September 2017).

117 Ibid.

118 Ibid.

119 Ibid.

120 Ibid.

121 Ibid.

122 Ibid.

123 Ibid. 


\section{When the Carnival is Over: The Case for Reform}

\section{Beyond Institutional Identity as an Organising Principle}

The Australian Law Reform Commission has noted that the utility of royal commissions 'depends in large part upon the extent to which their findings and recommendations are able to be acted upon and the uses to which their records may subsequently be put. ${ }^{124}$ Gaps in records management — such as those created by royal commissions ending without s 22(3) directions and/or s 22(6) arrangements in place-thus, inevitably undermine the practical value of the work of such commissions.

The regulatory deficiencies identified above are a consequence of the central premise of the existing legislative scheme; namely, that the complex institutional identity of royal commissions, particularly joint royal commissions, should in some way govern how records are dealt with once the relevant inquiry comes to an end. On the one hand, s 22(3) reflects a view of the royal commission as an executive entity. It betrays an assumption that there may be a department or agency of government better placed than the NAA to manage the care and custody of certain royal commission records (whether by reason of the nature or provenance of the records or the nature of the inquiry during which the records were produced). On the other hand, s 22(6) reflects a view of the royal commission as jurisdictionally bounded, reserving as it does a capacity for states and territories to exert control over the records of their own commissions.

These conceptions of the commission-as executive decision-maker with immutably jurisdictional character-admit of the potential for multiple archival authorities to become responsible for the documentary fruits of a commission's labour. The involvement of multiple archival authorities in turn creates risks to the integrity of the archive at multiple stages of the archival journey: from appraisal and acquisition to description and access. As Cook notes, concepts such as respect des fonds, original order and provenance serve to ensure that records are preserved 'as evidence of

124 Australian Law Reform Commission, above $\mathrm{n}$ 45, [8.4]. 
the functional-structural context and actions that caused their creation'. ${ }^{125}$ A dislocated approach to archives management also undermines the capacity of the royal commission to provide opportunity for critique of its findings and, as we suggested, has broad implications for its functions as a body of evidence, a repository of social, public memory and a tangible product of a non-binding inquiry.

\section{Towards Cooperative Centralisation}

In light of the complexities discussed above, the authors suggest that reform is necessary to facilitate greater public access to the content of the archive, and, in turn, greater critical understanding of the silences and priorities in its creation. Good archival practice also assists investigative processes ${ }^{126}$ and is central to ensuring that royal commissions are able to perform their roles as 'recognizable and repeatable components of a successful and reliable democratic civil society'. ${ }^{127}$

Pursuit of a general intergovernmental agreement, providing certain minimum standards for arrangements between the Commonwealth and a state (or states) for the purposes of s 22(6) of the Archives Act, could provide greater certainty around management of archival material and set a benchmark for community expectations of records management during, and after, the life of a commission. A general agreement of this type might provide for the types of documents that, in all cases, will go to the NAA, and for the custody in which those documents will be held once a commission ends.

However, relying on non-legislative means to provide for care, custody, use and access arrangements would not bind future governments in the establishment of new royal commissions. Nor would it address the serious legislative deficiencies arising from the interaction of the Royal Commissions Act 1902 (Cth), the Archives Act and state commissions

125 Terry Cook, 'Evidence, Memory, Identity, and Community: Four shifting archival paradigms' (2013) 13 Archival Science 95, 100.

126 Considering the relevance of archival practice to judicial inquiry, Barrera defines good archival practice as including identification of the institutional context in which documents have been produced, accurate archival descriptions and use of electronic resources: Giulia Barrera, 'Of Condors and Judges: Archival Musings over a Judicial Investigation' (2009) 9 Archival Science 203, 212.

127 Price and Smith, above n 44, 266. 
and public records legislation. In the context of joint royal commissions, reliance on ad hoc executive action to fill gaps in legislative prescription is particularly problematic.

At the best of times, intergovernmental cooperation can be fraught, piecemeal and dependent on the political will of the government of the day. In the context of commissions concerning issues of public trust or government accountability, it might be exceptionally difficult to disabuse participating jurisdictions of their possessive tendencies towards documents produced in, or by the governments of, each jurisdiction. So much can perhaps be inferred from the number of concluded joint commissions for which there are still no s 22(6) arrangements in place. Equally, legislative reform, particularly cooperative reform - that is, with the participation of more than one Australian jurisdiction-would require longer term commitment by participating jurisdictions and deeper intergovernmental cooperation, often at the highest levels of government.

Acknowledging these challenges, a cooperative scheme, supported by referrals of legislative power from the states, for the purposes of s 51(xxxvii) of the Constitution, offers the most effective means of achieving archival reform applicable to royal commissions. This might involve the Commonwealth Parliament being referred, to the extent necessary, the power to legislate with respect to the subject matter of royal commission records. ${ }^{128}$ Although the features of such a scheme are beyond the scope of this chapter, it bears repeating that any proposed model for archival reform would need to transcend the complex institutional identity of the royal commission, rather than accept it as an organising principle.

\footnotetext{
128 The Commonwealth would already have legislative power with respect to the records of Commonwealth royal commissions, but a referral may be necessary to empower the Commonwealth to legislate in respect of records of joint commissions that could be characterised as state documents. For an example of this approach, see the terms of the referrals supporting the Corporations Act 2001 (Cth): Corporations (Commonwealth Powers) Act 2001 (NSW) s 4; Corporations (Commonwealth Powers) Act 2001 (Qld) s 4; Corporations (Commonwealth Powers) Act 2001 (SA) s 4; Corporations (Commonwealth Powers) Act 2001 (Tas) s 5; Corporations (Commonwealth Powers) Act 2001 (Vic) s 4; Corporations (Commonwealth Powers) Act 2001 (WA) s 4.
} 
This text is taken from The Court as Archive, edited by Ann Genovese, Trish Luker and Kim Rubenstein, published 2019 by ANU Press, The Australian National University, Canberra, Australia. doi.org/10.22459/CA.2019.03 